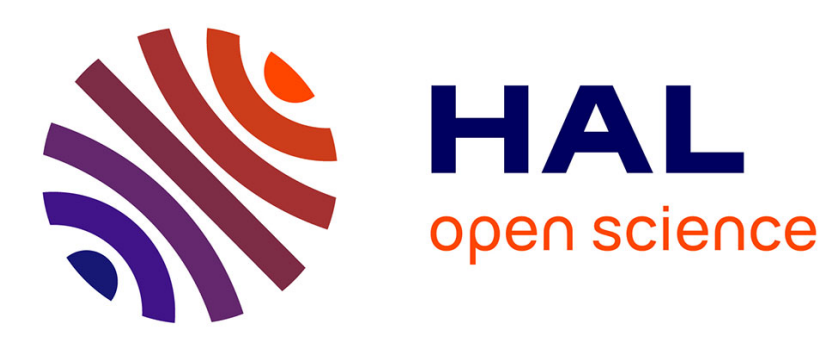

\title{
The potential of cleptoparasitic bees as indicator taxa for assessing bee communities
}

\author{
Cory Sheffield, Alana Pindar, Laurence Packer, Peter Kevan
}

\section{To cite this version:}

Cory Sheffield, Alana Pindar, Laurence Packer, Peter Kevan. The potential of cleptoparasitic bees as indicator taxa for assessing bee communities. Apidologie, 2013, 44 (5), pp.501-510. 10.1007/s13592013-0200-2 . hal-01201320

\section{HAL Id: hal-01201320 \\ https://hal.science/hal-01201320}

Submitted on 17 Sep 2015

HAL is a multi-disciplinary open access archive for the deposit and dissemination of scientific research documents, whether they are published or not. The documents may come from teaching and research institutions in France or abroad, or from public or private research centers.
L'archive ouverte pluridisciplinaire HAL, est destinée au dépôt et à la diffusion de documents scientifiques de niveau recherche, publiés ou non, émanant des établissements d'enseignement et de recherche français ou étrangers, des laboratoires publics ou privés. 


\title{
The potential of cleptoparasitic bees as indicator taxa for assessing bee communities
}

\author{
Cory S. Sheffield ${ }^{1}$, Alana Pindar ${ }^{2},{\text { Laurence } \text { PACKeR }^{2} \text {, Peter G. Kevan }}^{3}$ \\ ${ }^{1}$ Royal Saskatchewan Museum, 2340 Albert Street, Regina, Saskatchewan S4P 2V7, Canada \\ ${ }^{2}$ Department of Biology, York University, 4700 Keele Street, Toronto, Ontario M3J 1P3, Canada \\ ${ }^{3}$ School of Environmental Biology, University of Guelph, Guelph, Ontario N1G 2W1, Canada
}

Received 31 August 2012 - Revised 3 January 2013 - Accepted 28 January 2013

\begin{abstract}
Many factors affect bee diversity and abundance, and knowledge of these is crucial for maintaining healthy bee communities. However, there are few means to fully evaluate the status of bee communities; most are based on monitoring species richness and abundance and do not consider the diverse life histories of bees. We propose that functional diversity of bee communities offers a more consistent means of evaluation and suggest that cleptoparasitic bees in particular show much promise as indicator taxa. Cleptoparasitic bees play a stabilising role within bee communities. They represent the apex of bee communities and are the first guild to respond to disturbances, are easily distinguished as such and are diverse enough to be representative of entire bee communities. The diversity and abundance of cleptoparasites in relation to all bees is indicative of the status of the total bee community, and monitoring them should form an integral part of assessing bee communities.
\end{abstract}

\section{pollinator communities / guild structure / cleptoparasites / indicator taxa / ecosystem health}

\section{INTRODUCTION}

There is no denying that human-assisted environmental changes are taking place on a global scale and that these changes are having strong impacts on vital ecological processes through their effects on biodiversity (Balvanera et al. 2006). One such ecological process evidencing these impacts is pollination (Biesmeijer et al. 2006; National Research Council 2007), the success of which for most plants is linked to pollinators, including bees (Michener 2007). Bees are keystone components of most terrestrial ecosystems, pollinating plants in natural and managed settings (Biesmeijer et al. 2006; Klein et al. 2007). In

\footnotetext{
Corresponding author: C.S. Sheffield, cory.sheffield@gov.sk.ca Manuscript Editor: David Tarpy
}

the past decade, declines in bees and other pollinators have prompted much justified concern over the potential impacts to food production and ecosystem stability (e.g. Kremen et al. 2002, 2004; Biesmeijer et al. 2006; National Research Council 2007). As such, the need to understand which factors influence bee species richness (henceforth called "diversity") are crucial to promote plant reproduction, bee conservation and stewardship, and prevent the continued decline of pollinators (Williams et al. 2010).

In general, the diversity of a community influences its stability, productivity and susceptibility to invasion (Hooper et al. 2005; Cardinale et al. 2006; Duffy et al. 2007). However, for most regions of the world, very little historic or "baseline" bee community data exist for comparison to present data. In response, much recent work has been done to develop and evaluate monitoring schemes, 
which accurately reflect bee diversity (e.g. Toler et al. 2005; Roulston et al. 2007; Westphal et al. 2008; Grundel et al. 2011; Nielsen et al. 2011), many concluding that sampling methods differ with respect to capture efficiency and representation of fauna and that they often complement each other. Clearly, habitats differ dramatically with respect to the bee fauna as a whole, as some habitats and/or areas are naturally more species rich than others (Michener 1979, 2007). A general consensus is that anthropogenic habitats (e.g. agro-ecosystems) typically have lower bee diversity than surrounding natural habitats (Kremen et al. 2002, 2004; Cane et al. 2006; Klein et al. 2007). However, interpreting diversity data can often be difficult; although comparisons of specific metrics among sites (and studies) are possible, the utility of such data for diagnosing the status of bee communities within the habitat(s), thus serving as an ecological indicator, is not always straight forward. For instance, in our recent study (Sheffield et al. 2013), we used traditional approaches for analysing bee diversity in response to ecological disturbances, finding that diversity differed significantly between intensely managed apple orchards and unmanaged habitats, though habitats of intermediate management intensity (i.e. differing proportions of unmanaged/natural habitat) were most similar to either extreme (i.e. the highly disturbed habitats, or to unmanaged habitats), depending on the metrics used to evaluate diversity data. As such, conclusions drawn on the impact of habitat enrichment for pollinators would be considered effective, or not, based on the estimators of diversity used. Moreover, these metrics do not consider the diverse life histories of the bees; in most studies, bees are usually considered on the whole a group with similar ecological behaviours.

A potential solution is to incorporate life history traits into such analyses (Tilman and Lehman 2001; Moretti et al. 2009; Williams et al. 2010; Scrosati et al. 2011) as not all species are functionally, evolutionarily and ecologically equivalent (Chiarucci et al. 2011). Bees display a range of lifestyles, which can be assigned to nontaxonomic functional groups or "guilds"(sensu Blondel 2003) based on nesting biology, lifestyle, floral host specialisation, body size, etc. (Oertli et al. 2005; Moretti et al. 2009; Neame et al. 2012; Sheffield et al. 2013). This wide range of traits allows bees to exploit many habitats (Michener 2007; Williams et al. 2010), and monitoring the relative proportional abundance and diversity of members of these guilds provides additional information for describing and comparing communities (Sheffield et al. 2013). Bee guilds may show unique preferences and/or distinct requirements for habitat components (e.g. floral specialisation, nesting substrate preferences), and/or habitat type; different habitats will have specific guild profiles, and the guilds present in these habitats will show different responses to disturbance (Moretti et al. 2009; Neame et al. 2012; Sheffield et al. 2013). As such, guild profiles can be developed as baselines and, when considered together with other methods of assessing bee communities (e.g. standard diversity statistics, species abundance distributions, resulting fruit and seed set, seed yield, etc.), offer more information on the factors affecting bee communities within these habitats and their responses to disturbance, and better conclusions may be drawn with regards to the health of the ecosystem and/or how to improve it (Sheffield et al. 2013).

The main objective of this study is to demonstrate that assessment of bee communities should include the diverse life histories of bees in addition to traditional approaches of measuring species richness, diversity indices and/or abundance. We emphasise cleptoparasitic bees as indicator taxa for bee communities; a cleptoparasitic (or cuckoo) bee is one in which the adult female enters the nest of a non-conspecific host bee, oviposits in a natal cell and then departs from the nest; the cleptoparasite larva matures on the provisions stored for the host's larva (Rozen 2001). Benefits of a cleptoparasite-focussed approach are discussed, which is compatible with traditional approaches of bee community diversity. 


\section{MATERIALS AND METHODS}

\subsection{Study sites}

The analysis presented here is of a dataset previously published by Sheffield et al. (2013). In 2001 and 2002, 19 sites within the Annapolis Valley, Nova Scotia were surveyed for bees, each selected to represent habitats within an ecological gradient. Habitats ranged from highly managed agro-ecosystems through levels of partial (i.e. adjacent) unmanaged and natural habitat to old fields. The four habitat categories were the following: (1) COMM-A (five sites), commercially managed apple orchards surrounded by adjacent orchard blocks or other agricultural crops, etc.; (2) COMM-B (five sites), commercially managed orchard blocks isolated from other agricultural areas and/or usually surrounded by adjacent woodland or nonagricultural land; (3) ABAND (four sites), abandoned and/or un-managed orchard sites that have not been sprayed or otherwise managed for production for at least 10 years; and (4) OLD FIELD (five sites), unmanaged meadow or open habitats with adjacent woodlands. Further details on the study sites can be found in Sheffield et al. $(2008,2013)$.

\subsection{Site characterisation}

The surrounding habitat landscape at each site was further categorised using satellite maps, overlaid with a $24 \times 24$ grid, each grid cell representing $25 \times 25 \mathrm{~m}$, with the central sampling point at the centre of the grid (see Sheffield et al. 2013). A normalised measure of habitat dominance $\left(h_{\mathrm{D}}\right)$ (after O'Neill et al. 1988) was assessed; values of $h_{\mathrm{D}}$ range between 0 and 1 , with higher values indicating a landscape dominated by only a few cover types; values closer to 0 indicating proportions of land cover that are nearly equal. The following landscape classifications were used: (A) tree fruit orchard under intense management, (B) non-tree fruit agricultural cropland under intense management, (C) woodland, (D) pasture (no spraying, seasonal mowing), (E) residence, (F) meadow and $(\mathrm{G})$ abandoned orchard. Large bodies of water and paved areas occupying most of the surface of individual grid cells were subtracted from the total grid number. $h_{\mathrm{D}}$ was calculated at three levels for each site: (A) the inner $8 \times 8$ grid; (B) a $16 \times$ 16 grid, and $(\mathrm{C})$ the total $24 \times 24$ grid.

\subsection{Bee survey methods}

At each site, nine 12-oz yellow pan traps (Solo Cup Company; catalogue number PSB2Y 0099) were placed in a $3 \times 3$ grid, each pan trap separated by at least $10 \mathrm{~m}$. Trap contents were collected weekly and pan traps replaced. Although it is known that the use of pan traps of several colours (e.g. yellow, blue and white) (Toler et al. 2005) and/or use of several sampling techniques (Roulston et al. 2007; Westphal et al. 2008; Grundel et al. 2011; Nielsen et al. 2011) typically offers a fuller representation of regional bee faunas in most circumstances, the sampling method used here is consistent across all sites, and captures were representative of the bee fauna of Nova Scotia (Sheffield et al. 2013). Voucher specimens of bees collected in this study are held at the Packer Collection, York University (Toronto, Ontario, Canada) and the Royal Saskatchewan Museum (Regina, Saskatchewan).

\subsection{Data analysis}

For each site, data from all nine pan traps were pooled prior to analysis. Total guild structure of the bee communities in each habitat types was previously compared (Sheffield et al. 2013); each species was assigned to one of eight guilds based on their known biology and included (A) solitary ground-nesters, (B) social ground-nesters, (C) honey bees, (D) nonparasitic bumble bees, (E) cavity-nesters, (F) cleptoparasites and $(\mathrm{G})$ social parasites (Bombus subgenus Psithyrus). Sheffield et al. (2013) reported significant differences in the proportion of bees representing each guild for several guilds among habitats, including cavity-nesting bees, Bombus, and cleptoparasites; the present analysis focusses on the cleptoparasitic bee guild.

To demonstrate the diversity and abundance patterns of cleptoparasites within the four habitat types, data for this guild in each abundance octave were added to the truncated log-normal plots; species abundance data for each habitat were log transformed $\left(x=\log _{2} n_{i}\right)$ and fitted to a truncated log-normal 
distribution following Magurran (2004). Although measuring deviations in the fit to the truncated log-normal distribution has been suggested as a diagnostic for the assessment of ecosystem health (Hubbell 2001), including for bee communities (Kevan et al. 1997), our purpose here is to show a summary of cleptoparasite species richness and abundance versus other bees. Sheffield et al. (2013) offer further discussion of this metric for assessing bee communities.

For individual sites, the number of cleptoparasitic species and the Berger-Parker dominance index were regressed against the number of cleptoparasitic individuals. To determine the impact of landscape on bee diversity, the reciprocal of the Simpson's diversity index $(1 / D)$ and the proportion of cleptoparasitic individuals were regressed against $h_{\mathrm{D}}$.

\section{RESULTS}

\subsection{Bee diversity}

In both years, a total of 7,234 bee specimens, representing 146 species, were identified from yellow pans (see Sheffield et al. 2013, for complete list of species). Cleptoparasites were present in all habitat types, being proportionally most species rich and abundant in ABAND and OLD FIELD, but almost non-existent in COMM-A (Figure 1).

\subsection{Landscape effects}

Landscape structure at the smallest scale was the best predictor of both bee diversity and the percentage of cleptoparasitic bees; both variables increased in a similar fashion as $h_{\mathrm{D}}$ decreased (Figure 2A, D). As a larger proportion of the surrounding landscape was included, much smaller effects were observed (Figure 2B, E) on both bee diversity and cleptoparasites. At the largest scale, the reverse effect was observed, with bee diversity and the percentage of cleptoparasites decreasing as $h_{\mathrm{D}}$ increased (Figure 2C, F), though at this scale, unmanaged habitat types were the dominant land cover (Sheffield et al. 2013). In all cases, overall bee diversity and the cleptoparasites percentages followed the same pattern (Figure 2).
A strong relationship between the proportion of cleptoparasitic species and the proportion of cleptoparasitic individuals was observed across sites (Figure 3A); species richness and abundance increasing in ABAND and OLD FIELD habitats. This general trend was also supported in the truncated log-normal plots (Figure 1), indicating that abundance and diversity of cleptoparasites was much less in highly managed habitats (i.e. COMM-A) and increased in habitats with increasing levels of natural habitat. Dominant species were much more prominent in highly managed habitats, but decreased significantly as the proportion of cleptoparasites increased (Figure 3B).

\section{DISCUSSION}

Traditional approaches to bee diversity are not always fully informative with respect to the status of the habitats they represent, and in our previous analysis of these data, rarified estimates of species richness indicated that only in the most heavily disturbed habitats (i.e. COMM-A) was there significantly reduced diversity; no differences were found among all other habitat types (Sheffield et al. 2013). Other species richness estimators (i.e. "hidden" species in truncated lognormal plots, extrapolation-based methods) indicated that the natural habitats had significantly more species than all other habitats, which did not differ. In that study, Sheffield et al. (2013) indicate that these results suggest that agro-ecosystems with intermediate levels of natural habitat do or do not encourage bee species richness based on how the data are analysed. As such, diversity data alone may not always reflect habitat quality for bees, especially at intermediate levels of disturbance. Similarly, evaluating these bee communities based on diversity and abundance data, particularly measuring deviations in the fit to the truncated log-normal distribution, did not diagnose the "health" of these systems; all four habitats were not normally distributed (see Sheffield et al. 2013 for discussion). However, partitioning these plots to reveal cleptoparasite 


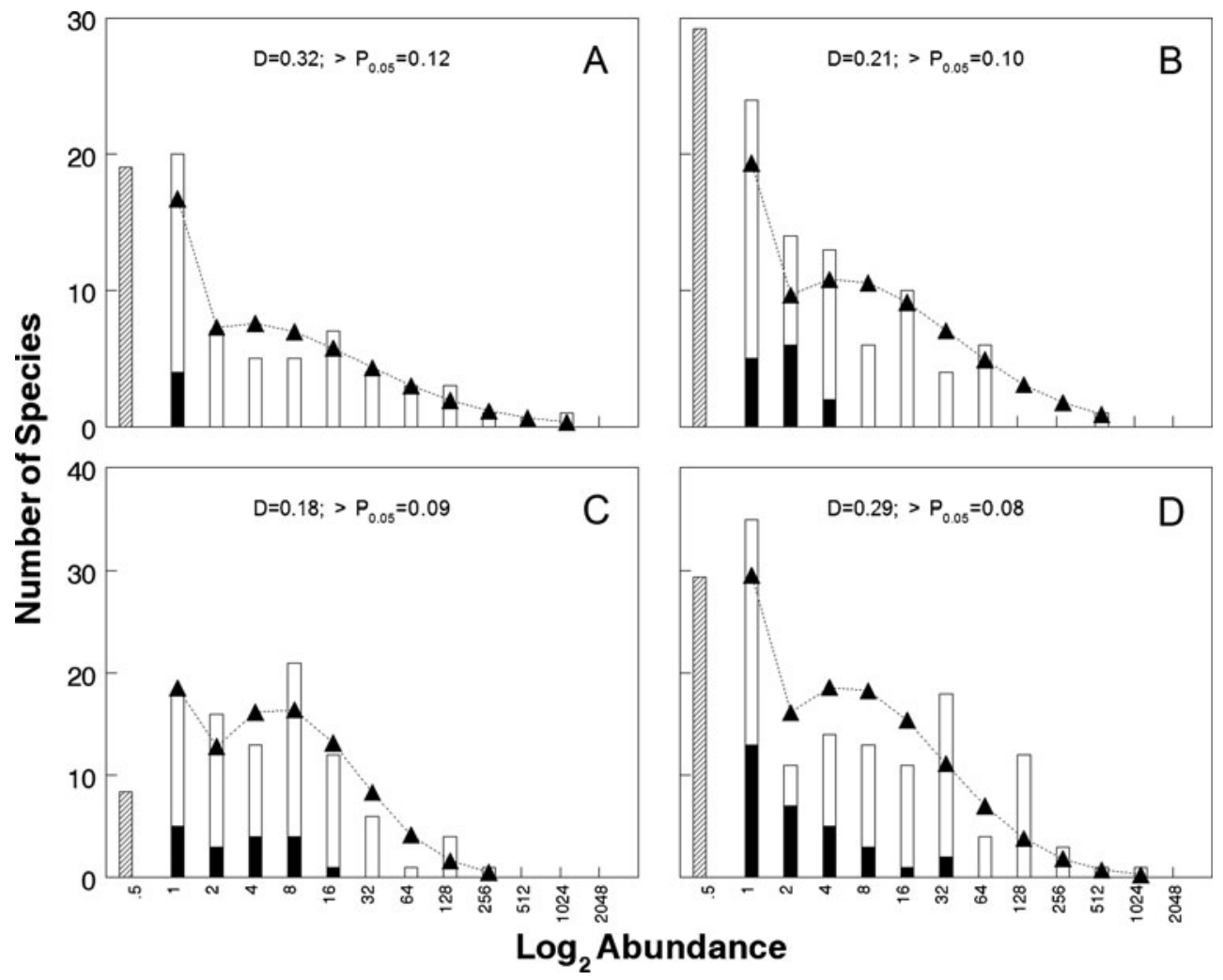

Figure 1. Truncated log-normal plot ( $\log _{2}$ scale) of observed (solid bars) and expected (triangles) bee species abundances, and estimated "unseen" species (diagonally striped bars) in A COMM-A, B COMM-B, C ABAND and D WILD habitats for 2001-2002. Kolmogorov-Smirnov test for normality with Lilliefors adjustment do not support a log normal distribution for any habitat type. Black sections of bars represent the number of cleptoparasites in each abundance octave.

diversity and abundance (Figure 1) clearly demonstrated that this guild was virtually lacking in the COMM-A habitat, becoming more diverse and comprising a larger proportion of the bee community as the landscape became more diverse with unmanaged habitat (Figures 2 and $3 \mathrm{~A}$ ).

Additional analyses that incorporate life history traits have much to offer to further understand bee communities and their responses to disturbances (Williams et al. 2010; Neame et al. 2012; Sheffield et al. 2013). Bees constitute an incredibly diverse assemblage of life histories, social structure, nesting biology, lifestyles, etc. (Michener 2007; Williams et al. 2010), which make it unreasonable to generalise the group as a whole, especially if habitat compar- isons and/or health evaluation are the subjects of investigation. Specific guilds respond differently due to specific requirements (Moretti et al. 2009; Neame et al. 2012), and incorporation of guilds into studies of bee communities may serve as an additional metric for measuring the status of the ecosystems (Sheffield et al. 2013). Natural habitats may have specific guild profiles; once determined (with enough regional sampling), these profiles may serve as benchmarks for pollinator community studies. As these profiles are guild-based and not exclusively taxonomy-based, comparisons across broader ecosystems may be possible, providing additional criteria to diagnose habitats and allowing comparisons among ecosystems that 

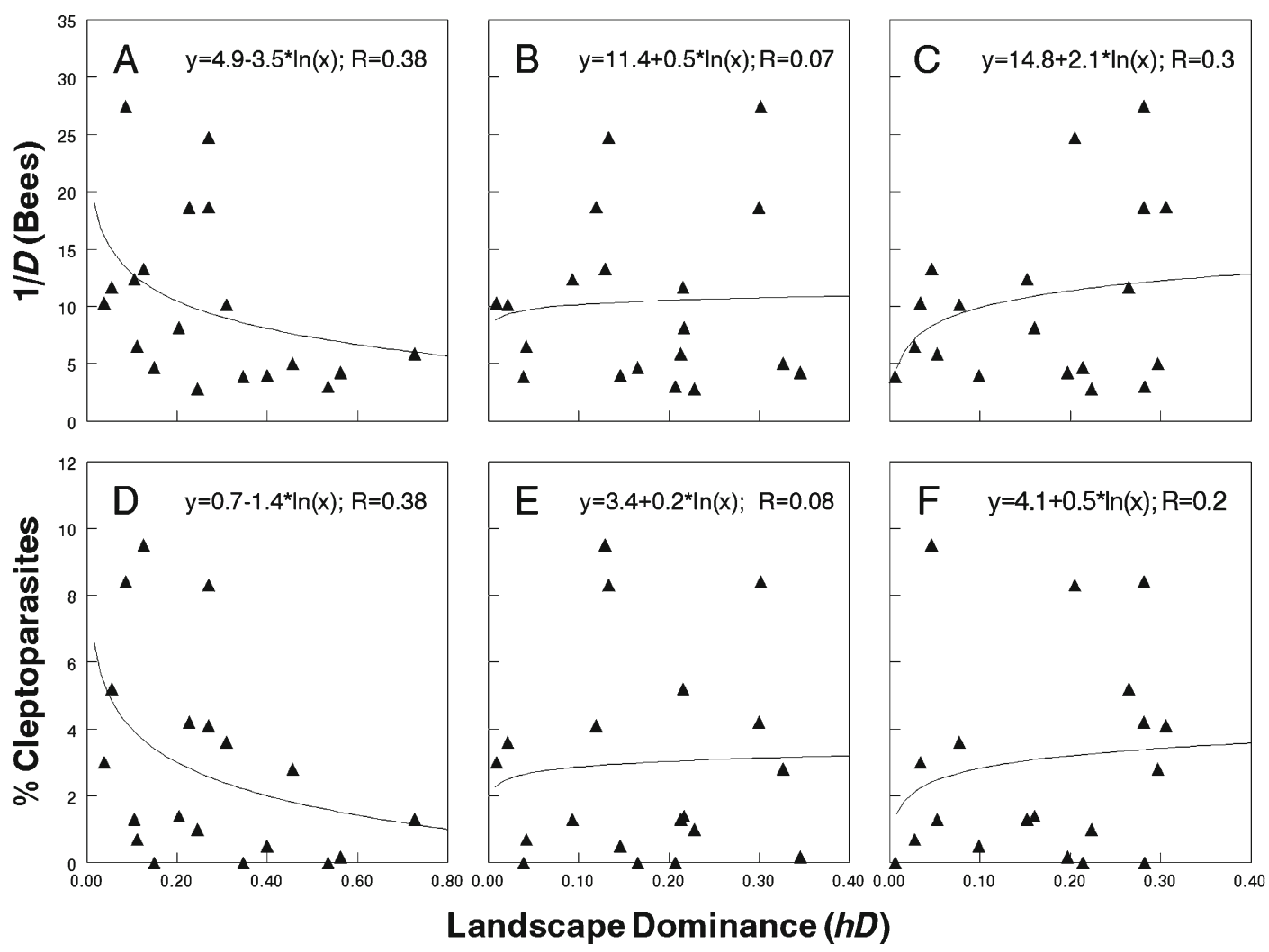

Figure 2. The diversity of bees $(1 / D)(\mathbf{A}-\mathbf{C})$ and percent cleptoparasites $(\mathbf{D}-\mathbf{F})$ versus landscape dominance $\left(h_{\mathrm{D}}\right)$ for each site at three landscape levels surrounding the sampled area: $200 \times 200 \mathrm{~m}(\mathbf{A}, \mathbf{D}), 400 \times 400 \mathrm{~m}(\mathbf{B}, \mathbf{E})$ and $600 \times 600 \mathrm{~m}(\mathbf{C}, \mathbf{F})$.

differ with respect to levels of disturbance or management (Tilman and Lehman 2001; Oertli et al. 2005). The rationale behind this approach is that loss of certain guilds, or functional diversity, within ecosystems can contribute to ecosystem collapse (O'Gorman et al. 2011), while the loss of species themselves may be buffered through overall species richness and redundancy (Walker 1992; Peterson et al. 1998; Elmqvist et al. 2003).

The quantity and quality of resources available to bees varies greatly among habitats, often attributable to the characteristics of the surrounding landscape (Kremen et al. 2002). Habitat type had a large impact on the proportional abundance of the different bee guilds (Sheffield et al. 2013), and strong negative responses to intense agriculture were observed in cleptoparasites in general (Figure 1), but more specifically in cleptoparasite diversity (Figure 3A). Reductions in cleptoparasite abundance in itself will cause an increase in the calculated proportion of other guilds, but when species alone are considered, no differences in the proportion of the guilds nor there diversity were observed (Sheffield et al. 2013).

There is a growing body of research suggesting that parasites and parasitism (in the general sense), like predation, are important factors in maintaining ecosystem health and stability (e.g. Combes 1996; Morand and Gonzalez 1997; Horwitz and Wilcox 2005; Marcogliese 2004; Hudson et al. 2006; Wood et al. 2007). In essence, cleptoparasitic bees may perform many of the same roles as true parasites. Despite the fact they are free living and kill the offspring of 


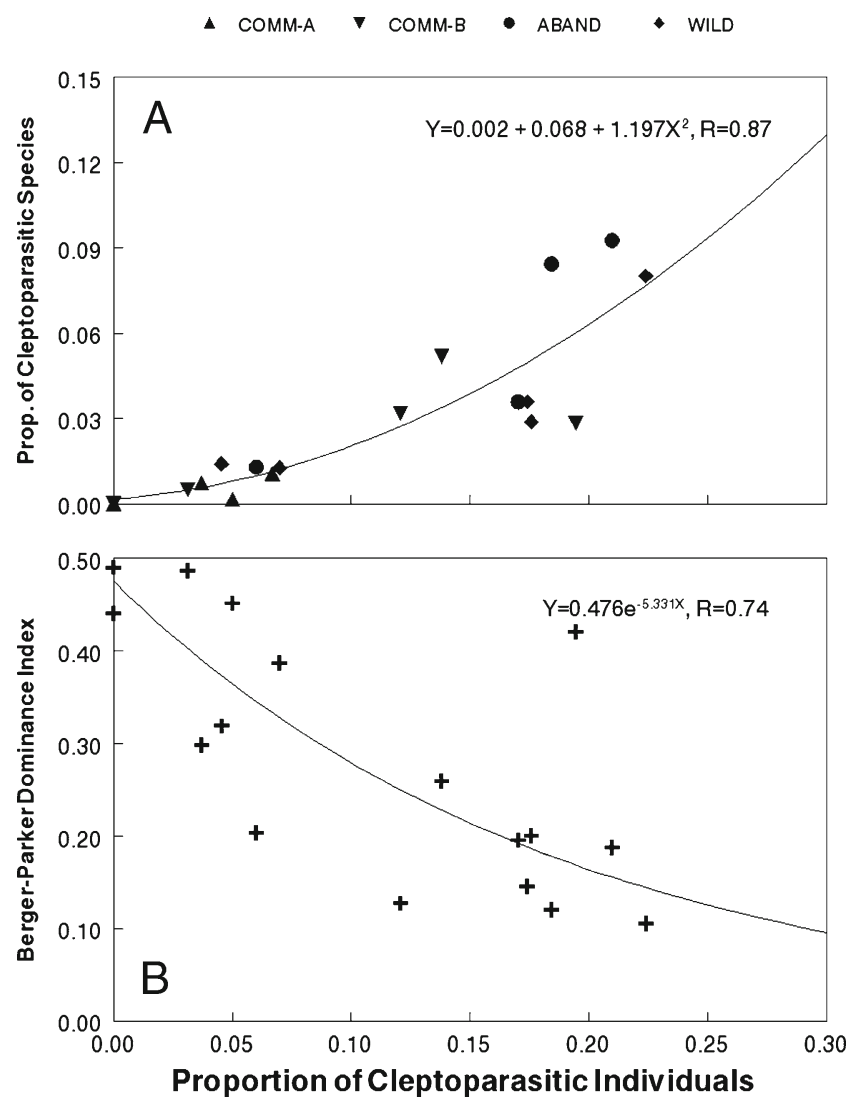

Figure 3. A The proportion of cleptoparasitic bee species versus individuals for sites from each habitat. B The Berger-Parker Dominance Index versus the proportion of cleptoparasitic individuals.

their host, like true parasites, they are reducing the fecundity of their host; depending on the taxon, either the cleptoparasitic larva kills the host egg (or developing larva) or the cleptoparasitic female destroys the host egg before she oviposits (Rozen 2001). Combes (1996) suggested that parasites perform a stabilising role, called "parasite arbitration" by effecting competition among hosts; cleptoparasitism itself is a form of competition (Iyengar 2008). In this study, sites with diverse and abundant cleptoparasite assemblages had lower dominance levels than in sites with few cleptoparasites (Figure 3B) supporting the idea that a stabilising role is being performed. Abundant host taxa are probably the most likely to be attacked in a given site and/or year, which may reduce competition among non-parasitic bee species; cleptoparasite activity is positively correlated with host nest density, not number (Polidori et al. 2009), though Rosenheim (1990) suggested that pressure from parasites (including cleptoparasites) may favour either aggregated or widely dispersed nesting strategies of host taxa.

The proportion of cleptoparasitic species to host species is usually low (Wcislo 1981), indicating that many cleptoparasites are probably generalists with respect to their hosts, though individuals probably focus on one host species during their lifetime (Bogusch et al. 2006). Cleptoparasites can make up a significant proportion of bee species in a geographic area, and many of the "rare" species in surveys belong to this guild (Oertli et al. 2005). They are ubiquitous, and the structure of cleptoparasitic bee communities follows those of the 
remaining bee community (Figure 2); there are generalist and specialist cleptoparasitic bees (though host information is known for very few), and their species richness and abundance is dictated by their hosts.

We believe that, among the guilds responding to different levels of disturbance, cleptoparasites have the greatest potential as indicator taxa for assessing bee communities. First, assigning bees to this guild is very easy; cleptoparasitic bees are, for the most part, easily recognised as such (Michener 2007). In contrast, the details of nesting biology of few bee species are actually known; megachilid bees, in particular, show such great variety of nesting habits, and some halictid bees (a large component of both solitary and social ground nesters) show even intraspecific variation in sociality (Michener 1974, 2007) that generalisations even at the level of genus are risky. Second, species richness often decreases upward from basal trophic levels in natural communities (Duffy 2003; Petchey et al. 2004). As such, the biology of cleptoparasites make them suitable as indicator taxa in a fashion similar to top predators and parasites (Marcogliese and Cone 1997) as they form the apex of bee communities; their presence within habitats is dependent on the presence of their host(s) and the resources available to and/or affecting these hosts (Finke and Denno 2004). The managed orchards had significantly fewer cleptoparasites (Figure 1A) despite these sites having the highest proportion of potential host species (i.e. solitary and social ground nesting bees) (Sheffield et al. 2013). As such, cleptoparasites were responding negatively to aspects of the sites in lieu of abundant host taxa. Disturbances within habitats that affect the species richness and/or fecundity of non-parasitic taxa through decline in availability of the resources needed by these bees may first be noticed in the relative abundance and diversity of cleptoparasites. Third, cleptoparasites are a diverse guild, and this lifestyle represents multiple independent origins in most bee families (Michener 2007) with a diverse assemblage of hosts. The effect of habitat disturbances on one or many host clades is likely to be observed and/or measurable within the cleptoparasitic guild as a whole. As such, and unlike other guilds, the cleptoparasite guild responds in ways that are reflective of the entire bee community (Figure 2), and probably serve as sensitive indicator taxa for assessing the status of ecosystems.

\section{ACKNOWLEDGEMENTS}

The initial study was completed as part of the requirements of the doctoral thesis of CSS. We thank the orchardists and land owners that kindly provided CSS access to properties throughout the study, and staff at the Atlantic Food and Horticulture Research Centre, Agriculture \& Agri-Food Canada for support. The initial work was funded by several Agri-Focus 2000 Technology Development Project grants and an AgriFutures grant to CSS. Further development of ideas presented here was funded by the National Science and Engineering Research Council (NSERC) Canadian Pollination Initiative (CANPOLIN) to LP and PGK. This is contribution number 68 of the Canadian Pollination Initiative.

Le potentiel des abeilles cleptoparasites comme taxa indicateurs dans l'évaluation des communautés d'abeilles

Communauté des pollinisateurs / guilde / santé des écosystèmes / espèces indicatrices

Die Möglichkeit, kleptoparasitische Bienen als Indikatoren zur Beurteilung von Bienengemeinschaften zu verwenden

Bestäubergemeinschaften / Gildenstrukturen / Kleptoparasiten / Indikatortaxa / Ökosystemstatus

\section{REFERENCES}

Balvanera, P., Pfisterer, A.B., Buchmann, N., He, J., Nakashizuka, T., Raffaelli, D., Schmid, B. (2006) Quantifying the evidence for biodiversity effects on ecosystem functioning and services. Ecol. Lett. 9, 1146-1156

Biesmeijer, J.C., Roberts, S.P.M., Reemer, M., Ohlemüller, R., Edwards, M., et al. (2006) Parallel declines in pollinators and insect-pollinated plants in Britain and The Netherlands. Science 313, 351-354

Blondel, J. (2003) Guilds or functional groups: does it matter? Oikos 100, 223-231 
Bogusch, P., Kratochvíl, L., Straka, J. (2006) Generalist cuckoo bees (Hymenoptera: Apoidea: Sphecodes) are species-specialist at the individual level. Behav. Ecol. Sociobiol. 60, 422-429

Cane, J.H., Minckley, R., Roulston, T., Kervin, L.J., Williams, N.M. (2006) Complex responses within a desert bee guild (Hymenoptera: Apiformes) to urban habitat fragmentation. Ecol. Appl. 16, 632644

Cardinale, B.J., Srivastava, D.S., Duffy, J.E., Wright, J.P., Downing, A.L., Sankaran, M., Jouseau, C. (2006) Effects of biodiversity on the functioning of trophic groups and ecosystems. Nature 443, 989992

Chiarucci, A., Giovanni, B., Scheiner, S.M. (2011) Old and new challenges in using species diversity for assessing biodiversity. Philos. Trans. R. Soc. London, Ser. B 366, 2426-2437

Combes, C. (1996) Parasites, biodiversity and ecosystem stability. Biodivers. Conserv. 5, 953-962

Duffy, J.E. (2003) Biodiversity loss, trophic skew and ecosystem functioning. Ecol. Lett. 6, 680-687

Duffy, J.E., Cardinale, B.J., France, K.E., McIntyre, P.B., Thébault, E., Loreau, M. (2007) The functional role of biodiversity in ecosystems: incorporating trophic complexity. Ecol. Lett. 10, 522-538

Elmqvist, T., Folke, C., Nyström, M., Peterson, G., Bengtsson, J., Walker, B., Norberg, J. (2003) Response diversity, ecosystem change, and resilience. Front. Ecol. Environ. 1, 488-494

Finke, D.L., Denno, R.F. (2004) Predator diversity dampens trophic cascades. Nature 429, 407-410

Grundel, R., Frohnapple, K.J., Jean, R.P., Pavlovic, N.B. (2011) Effectiveness of bowl trapping and netting for inventory of a bee community. Environ. Entomol. 40, 374-380

Hooper, D.U., Chapin, F.S., Ewel, J.J., Hector, A., Inchausti, P., et al. (2005) Effects of biodiversity on ecosystem functioning: a consensus of current knowledge. Ecol. Monogr. 75, 3-35

Horwitz, P., Wilcox, B.A. (2005) Parasites, ecosystems and sustainability: an ecological and complex systems perspective. Int. J. Parasitol. 35, 725-732

Hubbell, S.P. (2001) The Unified Neutral Theory of Biodiversity and Biogeography. Princeton University Press, Princeton

Hudson, P.J., Dobson, A.P., Lafferty, K.D. (2006) Is a healthy ecosystem one that is rich in parasites? Trends Ecol. Evol. 21, 381-385

Iyengar, E.V. (2008) Kleptoparasitic interactions throughout the animal kingdom and a reevaluation, based on participant mobility, of the conditions promoting the evolution of kleptoparasitism. Biol. J. Linn. Soc. 93, 745-762

Kevan, P.G., Greco, C.F., Belaoussoff, S. (1997) Lognormality of biodiversity and abundance in diagnosis and measuring of ecosystem health: pesticide stress on pollinators on blueberry heaths. J. Appl. Ecol. 34, 1122-1136

Klein, A.M., Vassiere, B.E., Cane, J.H., Steffan-Dewenter, I., Cunningham, S.A., Kremen, C., Tscharntke, T. (2007) Importance of pollinators in changing landscapes for world crops. Proc. R. Soc. B 274, 303-313

Kremen, C., Williams, N.M., Thorp, R.W. (2002) Crop pollination from native bees at risk from agricultural intensification. Proc. Natl. Acad. Sci. USA 99, 16812 16816

Kremen, C., Williams, N.M., Bugg, R.L., Fay, J.P., Thorp, R.W. (2004) The area requirements of an ecosystem service: crop pollination by native bee communities in California. Ecol. Lett. 7, 1109-1119

Magurran, A.E. (2004) Measuring Biological Diversity. Blackwell, Malden

Marcogliese, D.J. (2004) Parasites: small players with crucial roles in the ecological theater. EcoHealth 1, 151-164

Marcogliese, D.J., Cone, D.K. (1997) Food webs: a plea for parasites. Trends Ecol. Evol. 12, 320-325

Michener, C.D. (1974) The Social Behavior of the Bees. Harvard University Press, Boston

Michener, C.D. (1979) Biogeography of the bees. Ann. Mo. Bot. Gard. 66, 277-347

Michener, C.D. (2007) The Bees of the World, 2nd edn. Johns Hopkins University Press, Baltimore

Morand, S., Gonzalez, E.A. (1997) Is parasitism a missing ingredient in model ecosystems? Ecol. Model. 95, 61-74

Moretti, M., de Bello, F., Roberts, S.P.M., Potts, S.G. (2009) Taxonomical vs. functional responses of bee communities to fire in two contrasting climatic regions. J. Anim. Ecol. 78, 98-108

National Research Council (2007) Status of Pollinators in North America. National Academies Press, Washington

Neame, L.A., Griswold, T., Elle, E. (2012) Pollinator nesting guilds respond differently to urban habitat fragmentation in an oak-savannah ecosystem. Insect Conserv. Diver. 6, 57-66. doi:10.1111/j.17524598.2012.00187.x

Nielsen, A., Steffan-Dewenter, I., Westphal, C., Messinger, O., Potts, S.G., et al. (2011) Assessing bee species richness in two Mediterranean communities: importance of habitat type and sampling techniques. Ecol. Res. 26, 969-983

O’Neill, R.V., Krummel, J.R., Gardner, R.H., Sugihara, G., Jackson, B., et al. (1988) Indices of landscape pattern. Landscape Ecol. 1, 153-162

Oertli, S., Muller, A., Dorn, S. (2005) Ecological and seasonal patterns in the diversity of a species-rich bee assemblage (Hymenoptera: Apoidea: Apiformes). Eur. J. Entomol. 102, 53-63

O'Gorman, E.J., Yearsley, J.M., Crowe, T.P., Emmerson, M.C., Jacob, U., Petchey, O.L. (2011) Loss of functionally unique species may gradually undermine ecosystems. Proc. R. Soc. Lond. B 278, 1886-1893 
Petchey, O.L., Hector, A., Gaston, K.J. (2004) How do different measures of functional diversity perform? Ecology 85, 847-857

Peterson, G., Allen, C.R., Holling, C.S. (1998) Ecological resilience, biodiversity, and scale. Ecosystems 1, 6-18

Polidori, C., Borruso, L., Boesi, R., Andrietti, F. (2009) Segregation of temporal and spatial distribution between kleptoparasites and parasitoids of the eusocial sweat bee, Lasioglossum malachurum (Hymenoptera: Halictidae, Mutillidae). Entomol. Sci. 12, 116-129

Rosenheim, J.A. (1990) Density-dependent parasitism and the evolution of nesting aggregations in the solitary Hymenoptera. Ann. Entomol. Soc. Amer. 83, 277-286

Roulston, T.H., Smith, S.A., Brewster, A.L. (2007) A comparison of pan trap and intensive net sampling techniques for documenting a bee (Hymenoptera: Apiformes) fauna. J. Kansas Entomol. Soc. 80, 179-181

Rozen Jr., J.G. (2001) A taxonomic key to mature larvae of cleptoparasitic bees (Hymenoptera: Apoidea). Amer. Mus. Nov. 3309, 1-28

Scrosati, R.A., van Genne, B., Heaven, C.S., Watt, C.A. (2011) Species richness and diversity in different functional groups across environmental stress gradients: a model for marine rocky shores. Ecography 34, 151-161

Sheffield, C.S., Kevan, P.G., Westby, S.M., Smith, R.F. (2008) Diversity of cavity-nesting bees (Hymenoptera: Apoidea) within apple orchards and wild habitats in the Annapolis Valley, Nova Scotia. Canada. Can. Ent. 140, 235-249

Sheffield, C.S., Kevan, P.G., Pindar, A., Packer, L. (2013) Bee (Hymenoptera: Apoidea) diversity with- in apple orchards and old fields habitats in the Annapolis Valley, Nova Scotia, Canada. Can. Ent. 145, 94-114

Tilman, D., Lehman, C. (2001) Biodiversity, composition, and ecosystem processes: theory and concepts. In: Kinzig, A.P., Pacala, S.W., Tilman, D. (eds.) The Functional Consequences Of Biodiversity: Empirical Progress and Theoretical Extensions, pp. 9-41. Princeton University Press, Princeton

Toler, T.R., Evans, E.W., Tepedino, V.J. (2005) Pan-trapping for bees (Hymenoptera: Apiformes) in Utah's West Desert: the importance of color diversity. Pan-Pac. Entomol. 81, 103-113

Walker, B.H. (1992) Biological diversity and ecological redundancy. Conserv. Biol. 6, 18-23

Wcislo, W.T. (1981) The roles of seasonality, host synchrony, and behaviour in the evolutions and distributions of nest parasites in the Hymenoptera (Insecta), with special reference to bees (Apoidea). Biol. Rev. 62, 515-543

Westphal, C., Bommarco, R., Carré, G., Lamborn, E., Morison, N., et al. (2008) Measuring bee diversity in different European habitats and biogeographical regions. Ecol. Mono. 78, 654-671

Williams, N.M., Crone, E.E., Roulston, T.H., Minckley, R.L., Packer, L., Potts, S.G. (2010) Ecological and life-history traits predict bee species responses to environmental disturbances. Biol. Conserv. 143, 2280-2291

Wood, C.L., Byers, J.E., Cottingham, K.L., Altman, I., Donahue, M.J., Blakeslee, A.M.H. (2007) Parasites alter community structure. Proc. Natl. Acad. Sci. USA 104, 9335-9339 